\title{
FROM IOWA STATE NORMAL SCHOOL TO UNIVERSITY OF NORTHERN IOWA
}

\author{
By Katherine Buxbaum
}

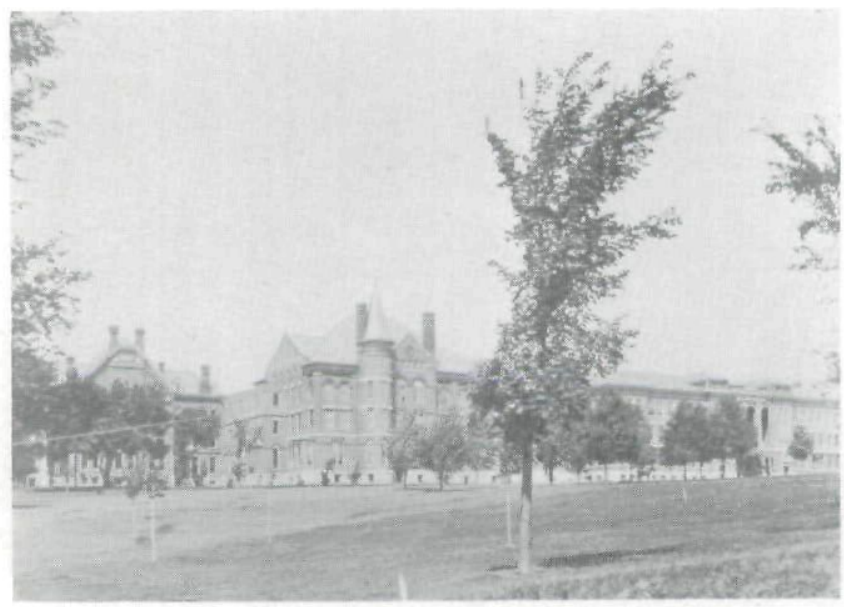

1915 View of I. S. T. C. Campus

When I was growing up, the Iowa State Normal School was not even a name to me. Probably most of my neighbors were only dimly aware that there was, 150 miles to the north of us, a thriving educational mill, busily turning out teachers for the elementary schools of the state. However, a few ambitious young women of our community, teachers in the rural schools of which they were a product, had heard of it and had begun to set their sights on Cedar Falls-they tended to use the name of the town rather than of the school itself. And in due course, they did take their hoarded savings and board the train for Cedar Falls, where, if they could stretch their funds, they could get a few terms of training which led to better certification and better positions, perhaps even in town schools. They came back home singing:

Boom, boom, de yay; boom, boom, de yay

I-o-wa No-or-mal; İo-oway. 
After that we began to speak of "the Normal."

When, much later, I got myself to Iowa City (then S.U.I., but alas, no more, since the scrambling of names of our state schools), I found among the students there a somewhat supercilious attitude toward the Normal. If we had known, or taken the trouble to find out that it was even then one of the best of its kind in the Mid West, we might have acknowledged its worth. I remember that we did give credit, in a class song to one of our more brilliant professors who was an import from there:

He has come to us from Normal, Where he was all the rage,

For they say he'd little trouble, In quoting many a page.

I did not at this time guess that I would some day join the teaching staff at the Cedar Falls campus and spend many fruitful years of my career there.

By the time I arrived at the school, it had a new nameIowa State Teachers College. This was something to be proud of since, as the only teacher training institution in the state, it had prestige as compared with Wisconsin, say. (That state, with its seven or eight normal schools, had smaller campuses and less generous appropriations.) The four year curriculum had been established in 1909. This supplemented the twoyear program which had aimed only at training teachers for the elementary grades. An excellent laboratory school, called at the time "the training school," ranked with similar departments at Peabody Institute and even Columbia University. The rapidly expanding campus could boast of several fine new buildings, one of them a Library Building with an impressive Greek facade which antedated the centralized library at the university by a good many years.

In the mid-twenties, Homer H. Seerley was still president, having served the school through a flourishing period of growth. He had gathered about him a faculty of varying degrees of scholarship, all of them dedicated as he was to the supreme function of educating the young. We heard little about research in those days, nothing about sabbatical leave, nor much even about going off to other campuses to do graduate work. So sure was President Seerley that a teacher's business was staying put and giving his all to his classes that he was once heard to murmur to one of his staff asking for leave 
to work on a masters' degree, "Just wonder why you don't get your education before you ccme here."

When, in 1928, Mr. Seerley did step down to make way for a progressive young man with a Ph.D. degree, it was with a graceful gesture. Ushering Ray Latham into his offlce he bade him sit down in the presidential chair and "write a letter to his mother." He then left the scene of his long labor without a backward look. With his going there was a noticeable loosening of the apron strings. To a devoted faculty he would always be the grand old man. But the paternalism that had characterized his regime was on the wane.

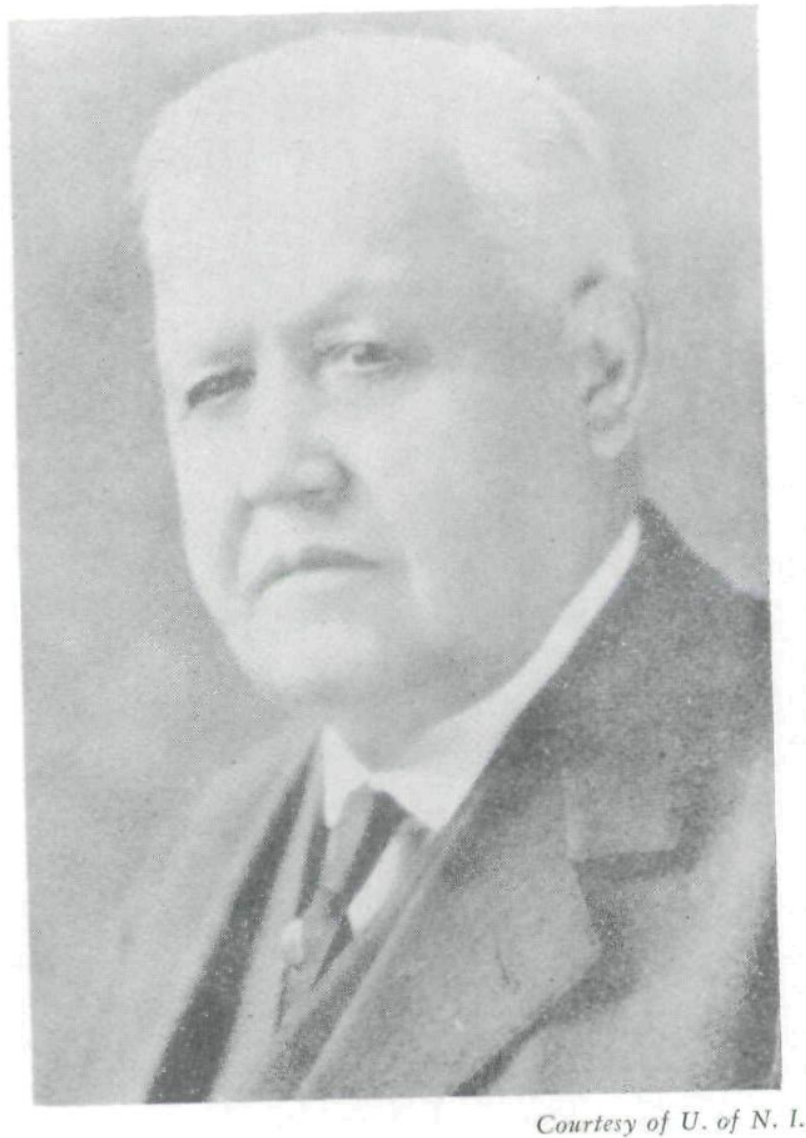

Homer H. Seerley, President from 1886-1928 
By this time the early days of I.S.N.S. had become almost a legend. But one of the original faculty was still with us. This was D. Sands Wright, an able teacher and a man of abundant charm. It was he who had taught the first class on that September day in 1876 when a handful of students gathered in the building, that had been the soldiers orphans home, for a venture in higher education. Listening to him when he told of that day, I could well imagine the red-cheeked, blackhaired young Quaker as he faced a class of eager young ladies, all waiting for scme word of wisdom. A little dismayed at the prospect, he had cast about for something that would serve as a starter. Then, leveling his eyes at the prettiest girl on the front row, he had demanded of her, "What is Grammar?" And on that portentous question the school was duly launched.

Another link with the past was C. A. Fullerton, who had graduated from the school in 1890. After a short apprenticeship elsewhere, he had returned as a full fledged faculty member and was socn made head of the department of vocal music. Much of this, of course, was public school music, which he managed to make interesting and even exciting. He could make even the least promising or the shyest girls step out in brisk tempo to the rhythm songs. Nimble of foot, he would show them how, and they caught his enthusiasm. When he took up the direction of the men's glee club, he welded the untrained voices of farm boys into a singing grcup which performed with skill and taste. This particular group was known by the romantic name of The Minnesingers, an organization that lasted down into the forties. There was a different leader by that time, but he had a respect for tradition. He never failed to close the progr m with an old favorite; he would turn to the audience and invite any former member of the Minnesingers who might be present to come forward and join in the singing of this number. We always loved that moment when these gentlemen, gray or graying, bald or balding, made their way through the aisles to the platform. The younger men moved back to make room; the conductor gave the nod-and never had the time-honored "Comrades in Arms" sounded so fine as when these blended voices of youth and 
maturity brought it again to life. The encore too was a classic, "The Winter Song," which ended on a sustained note of fraternal feeling:

And the cup is at the lip

In a pledge of fellowship.

At the spring concert in 1940, the 50th anniversary of the club, C. A. Fullerton himself was present. That night the applause rang loud and long. We should hardly let those Minnesingers go.

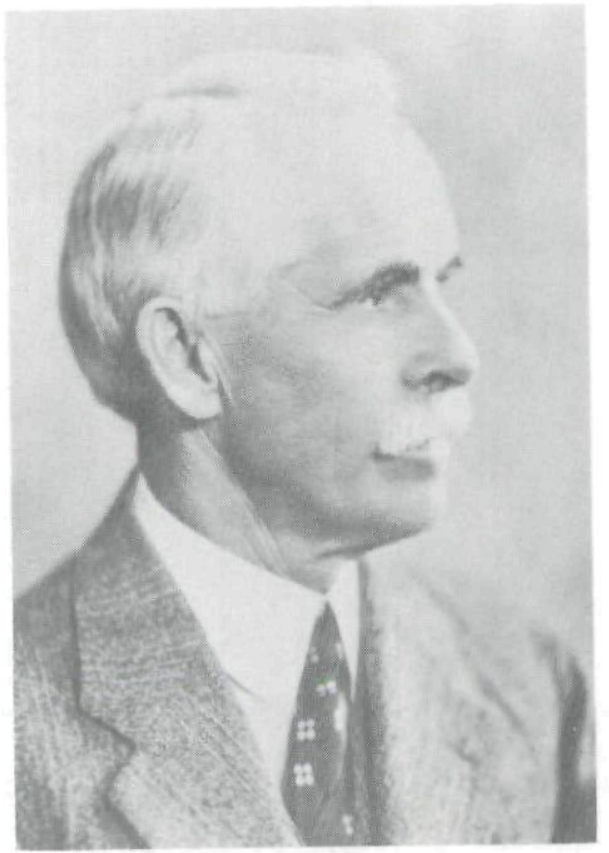

Courtesy of U. of N.I.

Charles A. Fullerton

I must mention one more, perhaps the most learned of the older group of faculty, F. I. Merchant, Professor of Latin and Greek. He had his Doctor's degree from the University of Berlin. I relished the tale of his brush with the examiners there who had asked, when he presented himself for the examination, what his field of study had been. They were a little cool, the candidate thought. Very likely they expected something related to technology-Americans were all prag- 
matists-and they seemed a little taken aback when he answered, "Classical Philology." Very well, then, but of course, in defending his thesis he would be expected to do it in German, to which Frank Merchant stoutly replied, "No, not in German. I will defend it in Latin."

In the 15 years that preceded World War II, strong winds of change were blowing across the campus. The curriculum felt the impact of modern educational philosophy. Faculty members went off to Columbia and came back preaching Deweyism. "Education for life-adjustment;" the need to educate "the whole child;" the Gestalt theory-these were a few of the phrases that caught on. In all the departments the tone was Progressive. In music, for instance, the cacophanies of Gershwin were first endured, then tolerated, then even liked. In painting, too. A fine collection of prints, old masters mainly, was purchased for the school. They were hung in the foyer of the library building where the townspeople, hungry for art, came on Sunday afternoons to view and admire. The exhibit included a little impressionism-blue horses, maybe. Here and there were found a hint of the abstractionist school with its meaningless curves and lines. But we were learning, learning not to insist that to be art a picture must be "about something" familiar.

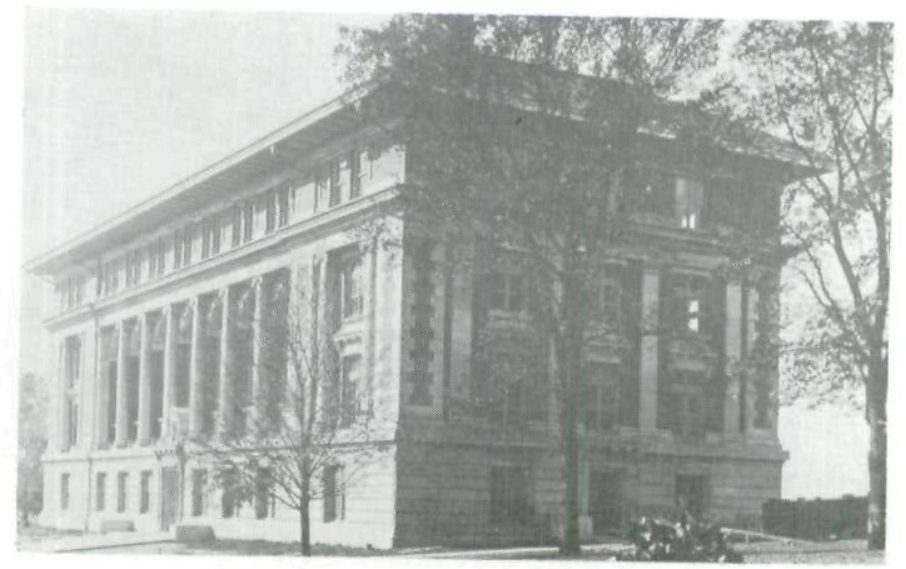

I. S. T. C. Library, Photo Taken in 1915. 
The wind of change affecting my own department, that of English language and literature, was a chilling one. That question, "What is Grammar," might have been of paramount importance in 1876 when grammar was a corner post of the educational system-when knowing it and practicing it was the mark of a cultivated man. And we had grown up with respect for its rules. Now we began hearing that rules as such were outmoded; they were not really English anyway, but a useless inheritance from Latin grammar. Text books coming off the presses warned us to be cautious about pronouncing on speech modes as correct or incorrect. The watchword now was Usage: what, really, did people say? If "It is me," "Who do you mean?" or "Do it like he does," were adequate for communication, these phrases should be accepted by educated persons. Let the cherished rules go. The multipication table and other phases of arithmetic teaching had already fallen afoul of the "new math." But innovations in that field did not cast doubt in one's gentility as lapses from grammar tended to do.

Our school felt considerable pride in being chosen as a training ground for the military in World War II. Now the Waves and the air cadets descended upon us, needing space for their classrooms and needing such housing as we were able to provide. A shrunken enrollment made it possible for us to care for the Waves; but, the quonsets moved in and they are still with us. We found the trainees of varying backgrounds interesting; we mingled their songs with "Cheer for dear I.S.T.C.”

I.S.T.C.-All through Iowa and in far flung places where our graduates had gone, the initials were familiar. Everybody knew what they stood for; they advertised the school's specialty. Then came the day when word got around that teachers colleges had lost caste. True, they had broadened their curricula and were now educating students for widely different fields of service. This more flexible program called for a name of broadened significance. Schools like ours all over the country were becoming "state colleges." Perhaps a hint of the low estate of normal schools, those quaint institutions from which most of them had evolved, lingered about the name of a teach- 
ers college. In 1961 our school fell in line and became the State College of Iowa. A casualty of this change was the college song with its lilting challenge, "O let the spirit of State Teachers College lift our praises as of old." The new name and initials did not fit.

So far as I know there was no new song written to take its place. Indeed there was scarcely time to write one, learn it, practice it, and get it into the blood stream of student life. A scant five years passed and another change was in the air. Our college was, for reasons best known to management, heading for university status. A student body of 7,000, with another 1000 clamoring for entrance, called for changes commensurate with its size and needs. There was protest, of course, from those who said, "We're not ready." But the Administration, the Regents, and finally the Legislature, provided enough leverage to overcome opposition to the change. It remained only to shape the right words into an appropriate title.

University of Northern Iowa will sound strange until we get used to it. But, after all, a name is little more than a handle. What the Normal School pledged itself to do for the state; what the College did, and did so well during 50 years of growth and influence, will, I suppose, continue to be a major concern of Iowa's third state university.

\section{THE INDIAN PAID HIS DEBT}

\section{By Sarah Wyatt and Margaret Pearl Morgan}

Our maternal grandparents, Thomas and Sarah Wyatt Jones, came to Iowa the second time in 1865 to remain as pioneers of this state. From their early home, which was a log cabin on a back 40 acres away from the later established road, our grandparents and family moved to another 40 acres and built a new house about 1870 . Our mother, the next to the youngest of the family, was born here and it was on this part of the farm that our grandparents and family spent many happy and yet sorrowful and tragic years. 
Copyright of Annals of Iowa is the property of State of Iowa, by \& through the State Historical Society of Iowa and its content may not be copied or emailed to multiple sites or posted to a listserv without the copyright holder's express written permission. However, users may print, download, or email articles for individual use. 